\title{
Projecting Mark Twain From Bohemia to Xinjiang
}

\section{Katherine E. Bishop}
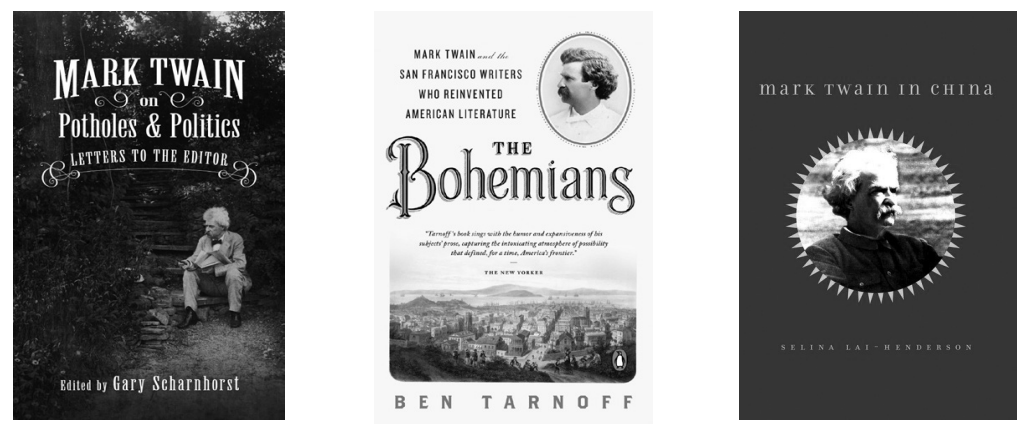

MARK TWAIN ON POTHOLES AND POLITICS: Letters to the Editor. Edited by Gary Scharnhorst. Columbia: University of Missouri Press. 2014.

THE BOHEMIANS: Mark Twain and the San Francisco Writers Who Reinvented American Literature. By Ben Tarnoff. New York, NY: Penguin Press. 2014.

MARK TWAIN IN CHINA. By Selina Lai-Henderson. Stanford, CA: Stanford University Press. 2015.

Although he did take up several pen names during his career, Samuel L. Clemens predominantly stuck with his most famous nom de plume, Mark Twain. If asked to imagine Twain, most people would call to mind his bushy hair, mustache, and eyebrows along with his signature white suit, and, perhaps, a cigar. Although his wardrobe was more varied than such a sketch would denote, 
Twain's look, in its wild stability, came to represent an immovable figure of the American frontier. For many, Twain's visage became the look of American letters: individual, a bit unkempt, and reassuringly familiar. But the relatively static vision of Twain's figure belies a multifarious oeuvre that continues to be reshaped and expanded by new readings and perspectives. More than that, it reflects his carefully scaffolded writerly persona: Twain's construction of his brand. Loren Glass's discussion of literary celebrity in Authors, Inc.: Literary Celebrity in the Modern United States, 1880-1980 (2004) and Judith Yaross Lee's recent contribution on the intersection of humor and postindustrial capitalism, Twain's Brand: Humor in Contemporary American Culture (2013) among others, have begun to draw back the curtain and examine the mechanisms afoot behind his celebrity. This work is continued in the three books at hand.

Twain's literary legacy begins, of course, with humor, his foremost trait—at least in the United States; as Selina Lai-Henderson explains in Mark Twain in China, Twain has long been principally an anti-imperialist elsewhere in the world. Only recently have translations been able to make strides with his comedic elements. Twain's humor propelled his first major American hit, the short story "Jim Smiley and His Jumping Frog," later republished as "The Celebrated Jumping Frog of Calaveras County," and other enduringly popular works. Encapsulating Western linguistic and comedic flair, "Jumping Frog" took both coasts by storm in 1865- how and why it did so are a few of the threads Ben Tarnoff unravels in The Bohemians: Mark Twain and the San Francisco Writers who Reinvented American Literature. Tarnoff explains that, as with everything, timing was key-Twain was able to take advantage of having settled in the West just before it, and its literature, were connected to the East by the transcontinental railroad. Figuring out how to sell America on frontier-steeped stories as an integral part of its image, and thus carving a path for himself into the national literary scene, Twain also made these images a central part of his own story. Moreover, letters to editors captured in miniature the charisma that Twain was known for on the lecture circuit and so provided an easily accessible forum for his conversational engagement with the public and self-shaping, as Gary Scharnhorst celebrates in Mark Twain on Potholes and Politics: Letters to the Editor.

In addition to allowing Twain to weigh in on topical issues and increase the market saturation of his voice, early letters, eventually transformed into the bestselling travelogue The Innocents Abroad, were lauded for capturing an essential, American point of view-and for doing so with verve. Popular readers and scholars alike are still interested in Twain's humor, his travel writings, and his "distinctly" American voice; however, as demonstrated in these three studies, his reputation has become increasingly complicated by works exploring the depths and vitality of his voice and vitriol. The revitalization of polemical tracts including "To the Person Sitting in Darkness" and "The United States of Lyncherdom" has attracted the attention of recent scholars (including those featured here), producing inquiries into the growth of his satire, the impetuses behind his texts, and the sustained socio-cultural effects of his writings. The end of Twain's hundred-year 
moratorium on his autobiography, the subsequent publication of the work as three volumes, and their consequential place in cultural conversations from book clubs to classrooms, too, has contributed to a popular hunger for and fascination with Twain's complexities: twenty-first century readers are nearly as entranced by his bile as they long have been with his "quintessentially American" humor. More and more, Twain's iconic wit has been recognized as an integral portal to deeper, fascinating rabbit holes from anti-imperialism to women's rights and transnational interpretations, illuminating more of the man and his milieu, and expanding the reach of what he means and to whom.

The Bohemians: Mark Twain and the San Francisco Writers Who Reinvented American Literature, Mark Twain on Potholes and Politics: Letters to the Editor, and Mark Twain in China accentuate Twain's manifold interactions with his, and our, worlds. They ask us to look with fresh eyes at Twain coming into his own - from the editorial broadsheet to Bohemian streets at home and abroad. They converge upon his acts of self-construction - through open letters, in conjunction with the American frontier, and in relation to global issues - while highlighting the contributions made by others, from public respondents in newspapers to Chinese revolutionaries looking to him for an ally. Scharnhorst's, Tarnoff's, and Lai-Henderson's studies all sally forth from San Francisco, California and engage with Twain's direct and indirect effects on literary and readerly scenes, tracing paths from Twain's formative environments to his development as a writer, thinker, and activist. They further contribute to recent discussions of the morphological nature of Twain's image, of his work in the publishing world, including his crusade to control the life of his texts through copyright, and of his deep marketing tactics.

At first blush, Mark Twain on Potholes and Politics may appear to be a somewhat kaleidoscopic assortment of 101 letters, many a handful of pages long, that Clemens as Twain submitted to editors for the sake of writing (and self-promotion) rather than remuneration. Of the letters Scharnhorst chose, all but eight were published shortly after Twain penned them, while four of those "either unmailed or mailed and not published" appear here in print for the first time (1). Spanning nearly fifty years, the letters' subjects are as varied as their regional, national, and international venues, which included the Hartford Courant, the Buffalo Express, the Californian, Harper's Weekly, Free Russia: The Organ of the English Friends of Russian Freedom, and the London Spectator. Ordered chronologically, the letters range from the moderate page-and-a-half long "Explanation of a Mysterious Sentence," published on 07 February 1866 in the San Francisco Examiner, an excoriation of the Chief of Police Martin J. Burke, to Twain's final two letters to editors (pithy squibs, really), in which he dryly affirms his continued corporeality, written on 24 December 1909 for the readers of the New York Times and 24 February 1910 for the New York Evening Journal. As many Twain aficionados would immediately notice, this time period does not comprise the entirety of Twain's journalistic career. A full history of Twain's contributions to the "letters to the editor" genre would include those he 
wrote to the Muscatine (Iowa) Journal in the decade prior to the earliest featured in this collection, the lot he sent in the early 1860 s from Virginia City in the Nevada Territory to the San Francisco newspaper, the Daily Morning Call, and others; however, compiling every letter to the editor Twain ever penned was not Scharnhorst's editorial intention.

As Scharnhorst optimistically explains at the outset, a number of the letters he selected are "relatively self-explanatory" and accessible enough so that his readers can, if they choose, "simply enjoy them" on their own (1). For those who are not experts on the "Byzantine politics of the French-Mexican War as it was concluding in 1866-67" (the subject of the third letter) - or who simply prefer their references elucidated and their editorials with a side of context, Scharnhorst provides concise and well-chosen annotations before, sometimes after, and as footnotes to the included letters (7). Throughout the volume, Scharnhorst guides and accompanies his readers with a light, dexterous hand. To the roughly pagelong letter parodying Secretary Seward and Minister Bigelow's correspondence on the French-Mexican War, for instance, Scharnhorst adds thirteen illuminating notes, smoothing out Twain's burlesqued version of the two men's already troublesome "telegraphic dispatches" (7).

In letter 39, a "classified ad" first published in the Hartford Courant on 20 May 1875, Twain "advertises" for his lost umbrella, offering \$5 for its returnand \$200 for the remains of the boy who had wandered off with it at a baseball game (87). One could imagine an overzealous editor including notes on the game itself - who played, the score, with whom Twain attended the match, the state of baseball in Hartford in the nineteenth century, and so on-but Scharnhorst contains his editorial comments to the letter, introducing it with six words, packed companionably with a reminder of the nigh-constant instrumentations of Twain's self-construction and promotion: "Even Twain's classified ads were entertaining."

The volume serves to heighten the pleasures of engaging with Twain's letters to editors by answering immediate queries. In addition to providing context for the selected letters, Scharnhorst drops breadcrumbs for future study. $\mathrm{He}$ confides that Mark Twain on Potholes and Politics "recovers a large body of his neglected and even unknown writings" that has been by and large ignored despite Twain's voluminous and excellent output (1). He reasons that Twain's letters to editors were valuable beyond their entertainment quotient, stating, "I believe Twain learned in these letters, by responding to various news reports and op-ed pieces, how to write in a cacophony of voices," hypothesizing that "some of these pieces are polyvocal experiments that anticipate Twain's works of proto-modern fiction, such as 'A Curious Experience' (1881) and 'The Great Dark' (1898)" (1-2). The forum provided by open publications such as letters to editors also created a field in which Twain could advertise his witty wares, as shown in a range of letters promoting his lectures overtly and covertly, and which now functions as a muted map to Twain's growth as a public interlocutor.

Where Scharnhorst props quick, minimal lines around Twain's letters, otherwise letting them stand for themselves, Tarnoff generously effuses color into 
Twain's Bay Area history. Tarnoff concentrates on Twain for vast swaths of the book as he chronicles the establishment of the burgeoning San Francisco literary scene. This is likely due in no small part to Twain's name remaining the most recognizable; it is also because, Tarnoff reasons, "[w] hat distinguished Twain from the others" began with "raw talent," developed into an ability to adapt himself to new environs while remaining "recognizably himself," and can be summed up as "relentlessness": he "experimented constantly" and "never stopped looking for new lines of attack" (255-56). But Twain is not The Bohemians's only fulcrum point. Tarnoff also weaves several of Twain's comrades into this history, particularly showcasing the rise and fall of Twain's friend-turned-rival, editor and author Bret Harte. Also included at the epicenter of the Bohemian movement are the frustrated poet Ina Coolbrith and the repressed Charles Warren Stoddard, a poet, short story writer, and, for a time, Twain's secretary. While Harte, Stoddard, Coolbrith, and Twain created a web of influences for one another essential to their individual developments and to the deep currents of American literature as Tarnoff charts them, the text's titular writers, Tarnoff admits, might not have actually formed a tight-knit group. Speaking of Coolbrith he writes, "[s]he almost certainly encountered Twain around this time, although they never became close. He left no record of her, and evidence for their friendship is scant. Her relationship to the rest of the Bohemians would be far more memorable" (82). Although it may have been more convenient for the book's argument to elide this sort of historical caesura, such admissions speak to Tarnoff's journalistic integrity.

The Bohemians recounts the period in the four writers' lives from 1863, when Twain began publishing in San Francisco, to 1878, when Harte permanently sailed for Europe. Reflecting the inchoate nature of the literary scene as they first encountered it, the narrative begins with a section titled "Pioneers." In it, Tarnoff traces his key players' entrées to their literary nexus, the Golden Era, a newspaper which would go from "an amateurish frontier rag to a savvy competitor on the national scene" as Twain, Harte, Coolbrith, and Stoddard would continue to publish in it, as well as the beginnings of brave ventures such as the launch of Charles Henry Webb and Bret Harte's vehicle for California writers, aptly titled the Californian (62). In "Pioneers," Tarnoff examines the writers' early works in conjunction with fundamental influences, including the humorist Artemus Ward; figures already established in the Bay Area literary scene such as Thomas Starr King, the Unitarian orator, and the socialite Jessie Benton Frémont; and the Angel's Camp mining community in which Twain heard a slew of tall tales, including one about a jumping frog. The last would inspire "Jim Smiley and His Jumping Frog," which Tarnoff, never one to waste an opportunity for imagery, calls "nothing less than the Fort Sumter of American letters" (105).

The second section, "Bonanza and Bust," finds Tarnoff's intrepid heroes beginning to face larger crises of faith and opportunities for greater rewards. It covers the publication of Twain's “Jim Smiley and His Jumping Frog” and Harte's "The Luck of Roaring Camp," the short stories that kicked off their respective literary careers. It also touches on Stoddard's discovery of inspiration in the 
tropics, Harte's launch of the literary magazine the Overland Monthly, Twain's success with The Innocents Abroad (1869), and his marriage to Olivia Langdon. Further, it digs into the racial unrest in San Francisco. Tarnoff identifies the influx of Chinese immigrants to California as imperative to the literature of the frontier, particularly Bret Harte's misconstrued, though popular, satirization of the "rising tide of anti-Chinese rage," entitled "Plain Language from Truthful James" (later "The Heathen Chinee") (187). Framing Harte's poem against a backdrop of the socioeconomic effects of the construction of the transcontinental railroad, Tarnoff explicates how "this nasty caricature would pay disastrous political dividends," heightening support for "the crusade against Chinese immigration" such as the restrictive 1875 Page Act and "Heathen Chinee planks" in both Republican and Democratic party platforms (189).

"Exile," the third section, recounts the final dissolution of the Bohemians as Twain, Harte, and Stoddard sought their fortunes elsewhere. It also covers the slow death of Harte's career, the continued rise of Twain's, and the end of their friendship. The latter was catalyzed by jealousy and the messy process of co-authoring the play Ah Sin in 1876. The epilogue, "Afterlife," finds Stoddard and Coolbrith, both still struggling to achieve literary success, reconnecting in San Francisco. It also provides a venue for Tarnoff to draw attention back to the often-overshadowed poet, describing her work as a librarian where she influenced a generation of children, including a young Jack London, and her eventual recognition in 1915 as the state's first poet laureate.

This group of writers, led initially by Harte but eventually captained by Twain, were essential to the development of a truly American literature. The Bohemians' irreverence, nonconformist tendencies, and drive, in other words, their very bohemianism, Tarnoff finds, "would help break the literary monopoly of the East" as well as "bring a fresh spirit to American writing, drawn from the new world being formed in the Far West"- and they would do so at just the "moment when the nation sorely needed new storytellers" (5). Their geographically-infused stories, poems, and plays would "awaken America to the fact of its bigness, to its infinite canvas of incident and character and slang" and nudge American literature "into a broader current - toward the discovery of a vast, varied continent composed of countless local cultures" (255).

As the above quotations show, Tarnoff's prose is one of the most immediately noticeable aspects of his work. He opens The Bohemians with a description of a young Twain's "brambly red brows and rambling gait" and "his strange way of speaking: a drawl that spun syllables slowly, like fallen branches on the surface of a stream" (9). Pages drip with such descriptions: on Twain's entrance to the Bay Area scene, he writes, "the carrot-haired rambler roared into California" (11); of Ina Coolbrith's visage, he judges "[h]er face breathed poetry through every pore" (32). Perhaps Tarnoff was inspired by Coolbrith's own "dazzlingly romantic hues" (33). Some readers might take umbrage at his dismissal of Mary Elizabeth Braddon as a "best-selling genre hack" but those who pine-for themselves or their students - for literary histories incorporating a depth of research from pri- 
mary and secondary sources but unencumbered by sesquipedalian prolixity will appreciate this romp through four diverging lives central to nineteenth-century American literature (84).

For readers who are looking for a literary frontier beyond the bohemian hills of San Francisco, in Mark Twain in China, Lai-Henderson takes up topics too-rarely discussed in Western conversations about Mark Twain: his stance on the Chinese in the United States, especially San Francisco; China, including the fin-de-siècle Boxer Uprising; and the translation, reception, and impact of Twain's work in Mainland China, Taiwan, and Hong Kong. Although Twain visited a large portion of the globe, exploring the Sandwich Islands; tramping all over Europe from Austria to Turkey; and following the equator to Australia, New Zealand, and Mozambique, he did not make it farther into the Asian continent than India and then-Ceylon (now Sri Lanka). This does not mean that his literary progeny failed to make the journey, however. As Lai-Henderson attests, Mark Twain has attained great fame in China, reasoning that "the brilliance and lasting popularity of Twain's work lies in its being effectively used to suit different political implications, especially in regions whose political and national values conflict with those of the People's Republic of China" (10).

The first three chapters focus on Twain's writings on the Chinese in America. Lai-Henderson claims that they are not simply valuable in their own right, as indeed they are, but also key adjuvants for Twain's later writings opposing oppression and imperialism. For instance, while Tarnoff concentrates on the negative aspects of the Twain-Harte collaboration, Ah Sin, calling it "a moral failure" and "a betrayal not just of their principles but of their Bohemianism —of the outsider ethos that imbued San Francisco's literary boom" (245-46), LaiHenderson argues it is "an indispensable work of Twain's for understanding his relationship with the Chinese," finding it to be more complex and critical than has traditionally been contended (31).

Like Tarnoff and Scharnhorst, Lai-Henderson first looks to Twain's formative years as a journalist in Virginia City and San Francisco. Similar to how Tarnoff sees in Twain's journalistic satire a maturation that eventually mirrors "the same morality that later made Huckleberry Finn refuse to betray his friend Jim," LaiHenderson zooms in on those elements of Twain's Bay Area journalism connected specifically to the advancement of his sympathetic feelings toward black Americans, Chinese immigrants, and Boxers (104). These developing racial and social attitudes, avers Lai-Henderson, were sparked by offenses against Chinese immigrants that he witnessed in California and Nevada.

Because Twain had grown up inculcated to racism aimed at black Americans, Lai-Henderson posits, seeing more of the same in San Francisco would not have had the same catalyzing effect on his consciousness as the oppressive treatment of the less-familiar Chinese. Lai-Henderson intriguingly speculates, "if the racism that he witnessed in California had targeted black people instead of Chinese, it is indeed unlikely that he would have undergone the same level of transformation that he did; the familiar racial dynamics might not have elicited 
such a strong epiphany in the first place" (5). This hypothesis is interesting but ultimately specious. More convincing is the consideration that writing a series of sketches featuring Chinese immigrants, "Disgraceful Persecution of a Boy," "John Chinaman in New York," and "Goldsmith's Friend Abroad Again," for the Galaxy in 1870 helped "Twain to realize that the deprivation of the basic human rights of the Chinese is not the fault of the Chinese themselves but is the result of the selfish political agenda of his own people ... owing to a morally deformed social environment" (21-22). While it is not precisely true that "Twain's first writings against American racism dealt with the oppression of the Chinese rather than that of black Americans," as Lai-Henderson argues, and so serve as "in effect, a rehearsal for his satires focused on racism toward African Americans" (4-5), many of his earliest known writings on socio-political inequalities do stem from his California- and Nevada-based journalistic education. He indeed saw and wrote on many events in this era that appear to have had long-ranging effects on his national and international outlooks. In "Blessings of Civilization: Mark Twain's Anti-Imperialism and the Annexation of the Hawai'ian Islands," for example, James Caron argues a similar spark can be found in Twain's 1866 letters from the Sandwich Islands to the Sacramento Union, letters which show a "profound ambivalence" about the expansion of American economic and social forces in Hawai'i (54). This spark would later detonate in incisive anti-imperialist essays such as King Leopold's Soliloquy (1905).

It is at the turn in the text where Lai-Henderson explores the reception and transformation of Twain's work in China that Mark Twain in China truly shines. In the final two chapters, "Lighting Out for the Pacific: Mark Twain's Posthumous Journey Across China" and "Translation, Appropriation, and Continuation: Huck Finn's Chinese Adventures in the Late Twentieth Century and Beyond," Lai-Henderson explores the challenges of importing and translating Twain's texts into and for Hong Kong and Mainland China. The transmogrifications of both his reputation and texts prompted by the New Culture Movement, the May Fourth Movement, and the Chinese Cultural Revolution are also analyzed. LaiHenderson contends that Twain has been "largely labeled a great humorist" in Western scholarship," but that "Chinese scholarship, on the contrary, displayed an early awareness of Twain's anti-imperialism" and has continued to primarily focus on Twain's political sides for several reasons (73). First, many Chinese readers and translators have identified with Twain's political tendencies, finding inspiration and solidarity in it. Second, Twain's humor has been difficult to convey: "Twain initially came across as quite a serious writer" as "much of the American humor was lost in the process of translation" (84).

However difficult Twain's humor has been to translate, his vernacular English may have posed even more problems for Chinese translators. Paying close attention to language and characterization in Adventures of Huckleberry Finn (1884), Lai-Henderson explains the challenges of capturing Huck's youthful voice, Jim's malapropisms, and Pap's racism, contrasting strategies used in a number of prominent translations. Much of the section on Pap's language centers 
on the difficulties of translating the "N" word that Chinese translators faced. Their problems are related to, but different from, those concerns surrounding the word found in Western critical circles, as explicated by Robert T. Tally Jr. in "Bleeping Mark Twain?: Censorship, Huckleberry Finn, and the Functions of Literature." Should the deeply offensive word be included in new editions of Huckleberry Finn, many US schools and scholars ask, prompting added questions related to censorship and meaning making. As there is no corollary to the "N" word in Chinese, Chinese translators have struggled with functional and appropriate stand-ins, a work made even more complicated by the shifting political atmosphere in China surrounding the Cultural Revolution.

Similar to Tarnoff's consideration of the Bohemians' impact on American literature, Lai-Henderson underscores Twain's serious cultural work in China. Partially because many of Twain's stories came to China by way of Japan, LaiHenderson claims they "indispensably contributed to the early process of bringing transnationalism into the Chinese literary community" (8). At first, Twain's works not only provided an outlet for an embrasure of vernacular Chinese, but also colored him "an ally and a heroic figure because he spoke up for Chinese immigrants against US oppression in the American West and later declared his support for the Boxers against US and European imperialism" (130). During the Cold War, Lai-Henderson argues, translating Twain's works could be interpreted "more as a symbol of free-thinking individualism against oppressive governments than as a work offering the everyday language of the local people" (99). In addition, as Lai-Henderson details in the epilogue, although the socio-political elements in Adventures of Huckleberry Finn do not have exact analogues in Chinese culture, the struggles between the majority Han Chinese and minority ethnic groups in many ways echo those found in Huckleberry Finn. In this reading, the border states stand in for the territory Huck threatens to light out for in order to avoid "sivililzation" (or "sinisization," as Lai-Henderson cleverly turns Huck's catch phrase) (129).

While drawing much needed attention to vital issues, Lai-Henderson's deep focus on China and Chinese immigrants occasionally bevels a false edge to some of Twain's writings and actions, including his own reportedly anti-Chinese statements. For example, it is true that he "described the Chinese that he saw for the first time in New York as "human vermin"' (3). But this equation was not quite so direct as Lai-Henderson's statement indicates; Chinese immigrants were only one part of the diverse urban group he was then slurring. In the full letter to his mother he sent in August 1853, it is made clear that people from every ethnic background are being denigrated. Though this dissemblance is clarified in another nine pages, the image has already been implanted by the time Lai-Henderson quotes more fully from the letter: "“[n]iggers, mulattoes, quadroons, Chinese, and some the Lord no doubt originally intended to be white, but the dirt on whose faces leaves one uncertain as to that fact, block up the little, narrow street'; 'to wade through this mass of human vermin,' he went on, 'would raise the ire of 
the most patient person that ever lived"' (12). The initial over-emphasis grants greater magnitude to his later defense of Chinese residents of San Francisco, Chinese Boxers, and others, conveniently serving Lai-Henderson's argument that his social consciousness was awakened by the visible offenses against Chinese immigrants in the Bay Area.

Another moment of weakness lies in Lai-Henderson's misreading of "The United States of Lyncherdom," the polemic Twain wrote in response to a slew of lynchings in Missouri in 1901. Wrapped in a powerful discussion of Twain's "little known and rarely discussed short story 'The Fable of the Yellow Terror' (written ca. 1904-1905)," an anti-imperialist animal tale, Lai-Henderson declares it "appalling" that Twain goes "so far as to invite China to witness the lynching activities in his southern hometown" $(70,72)$. Although Twain does issue an invitation in "The United States of Lyncherdom," it is not to China. In the long-unpublished essay, Twain instead invites American missionaries to return from China: he writes that it is not Chinese citizens but those of the United States who could most sorely use their help given that the so-called Christians at home were enacting unchristian hate crimes. That there are also a handful of chronological inaccuracies requires mention in a review. Such imprecisions snag upon careful readers and weaken the ground around several of the text's foundational arguments.

Despite Mark Twain in China's occasional faults, Lai-Henderson's precise handling of linguistic and cultural translations resonates as especially valuable contributions to Twain studies and transnational literary scholarship, joining recent works in which Twain's perspectives on Asia-related issues are at the forefront. These offerings include Tsuyoshi Ishihara's Mark Twain in Japan: The Cultural Reception of an American Icon (2005), Susan Harris's God's Arbiters: Americans and the Philippines, 1898-1902 (2011), and Hsuan L. Hsu's recent Sitting in Darkness: Mark Twain's Asia and Comparative Racialization (2015).

Moreover, Lai-Henderson is a generous writer. While we all stand on the shoulders of giants, some attempt to bury their predecessors with footnotes: LaiHenderson splays her sources out clearly in the text, putting her readers before critical legerdemain.

All three of these titles accomplish the daring feat of not simply challenging but re-envisioning the ever more dynamic images of Mark Twain circulating in popular and scholarly imaginations, both those he carefully nurtured and those autonomously cultured. The correspondence and editorial comments in Mark Twain on Potholes and Politics embrace the ethos that sometimes less is more. There is beauty in simplicity here as well as plenty of room for the interlocutor to inhabit the text. The Bohemians vividly captures the period and stakes of becoming a writer for Twain, Harte, Stoddard, and Coolbrith, breathing life into the mid-nineteenth century literary landscape and showcasing how Samuel Clemens became Mark Twain. Lastly, Mark Twain in China reveals angles and nuances of Twain's career and work that the man himself could not have anticipated. Drawing on literary studies, book history studies, and translation studies, Lai- 
Henderson's, Tarnoff's, and Scharnhorst's books all pull from Twain's California past to chart previously unexplored courses in the factors behind and mutations of Twain's and his texts' celebrity and afterlives.

\section{Works Cited}

Caron, James E. "Blessings of Civilization: Mark Twain's Anti-Imperialism and the Annexation of the Hawai'ian Islands." Mark Twain Annual 6.1 (2008): 53-61. Print.

Tally, Robert E. "Bleeping Mark Twain?: Censorship, Huckleberry Finn, and the Functions of Literature." Teaching American Literature: A Journal of Theory and Practice 6.1 (2013): 97-108. Print. 
